\title{
Review
}

Journal of Innate

Immunity
J Innate Immun 2010;2:228-237

DOI: $\underline{10.1159 / 000283688}$
Received: October 1, 2009

Accepted after revision: November 30, 2009

Published online: February 10, 2010

\section{Inflammatory Caspases in Innate Immunity and Inflammation}

\author{
Amir S. Yazdi Greta Guarda Marthe C. D'Ombrain Stefan K. Drexler \\ Department of Biochemistry, University of Lausanne, Epalinges, Switzerland
}

\section{Key Words}

Apoptosis · Autoinflammatory diseases $\cdot$ Caspases $\cdot$ NLRs . Inflammation •Inflammasome

\begin{abstract}
Caspases are best known for their role in apoptosis. More recently, they have gained prominence as critical mediators of innate immune responses. The so-called 'inflammatory caspases' include human caspase- $1,-4,-5$ and -12 and murine caspase-1, -11 and -12 . Of these, caspase- 1 is best characterized and serves as the prototype for our understanding of the processing, activation and function of inflammatory caspases. Like their apoptotic counterparts, inflammatory caspases are produced as inactive zymogens and require activation to become proteolytically active. Caspase- 1 is activated within the inflammasome, a large cytosolic protein complex that is induced by a growing number of endogenous, microbial, chemical or environmental stimuli. The importance of caspase-1 in initiating innate immune responses is demonstrated by its role in cleaving pro-IL-1 $\beta$ and pro-IL18 to their biologically active forms. New functions have also been implicated, as these proteases and the mechanisms underlying their activation and regulation emerge as important mediators of human health and disease.
\end{abstract}

Copyright $\odot 2010$ S. Karger AG, Basel

\begin{tabular}{|c|c|}
\hline KARGER & $\begin{array}{l}\text { (c) } 2010 \text { S. Karger AG, Basel } \\
1662-811 X / 10 / 0023-0228 \$ 26.00 / 0\end{array}$ \\
\hline $\begin{array}{l}\text { Fax +4161306 } 1234 \\
\text { E-Mail karger@karger.ch } \\
\text { www.karger.com }\end{array}$ & $\begin{array}{l}\text { Accessible online at: } \\
\text { www.karger.com/jin }\end{array}$ \\
\hline
\end{tabular}

\section{Introduction}

Caspases (cysteine aspartic acid proteases) are a family of highly conserved cysteine proteases that play key roles in apoptosis, development and inflammation [1]. In general, caspases exist in the cell as inactive pro-forms that require either proteolytic cleavage or oligomerization to become activated [2] (fig. 1a). Caspases share a common structure, consisting of a 3 - to $24-\mathrm{kDa}$ N-terminal prodomain, a 17 - to $21-\mathrm{kD}$ a central, large domain, and a 10 - to $13-\mathrm{kDa}$ small $\mathrm{C}$-terminal catalytic subunit domain. All caspases contain an active cysteine residue in their large central domain and show specificity in cleavage after an aspartate residue in their respective substrates. Caspases can be classified according to their function as either apoptotic initiator, apoptotic effector or inflammatory caspases (fig. 1b).

The apoptotic initiator caspases (caspase-2, -8, -9 and -10) share homology with the Caenorhabditis elegans cell death gene, ced-3 [3], and possess a long N-terminal prodomain that contains two death effector domains (DED; caspase-8 and -10) or a single caspase recruitment domain (CARD; caspase-2 and -9; fig. 1b). Pro-caspase- 8 and -10 are activated to initiate apoptosis by recruitment to the death-inducing signaling complex (DISC) via homotypic DED interactions with the adaptor protein FADD (Fas-associated protein with death domain). This extrinsic pathway is induced following activation by

Dr. Stefan K. Drexler

Department of Biochemistry, University of Lausanne

Chemin des Boveresses 155

$\mathrm{CH}-1066$ Epalinges (Switzerland)

Tel. +41 2169257 43, Fax +41 2169220 15, E-Mail stefan.drexler@unil.ch 


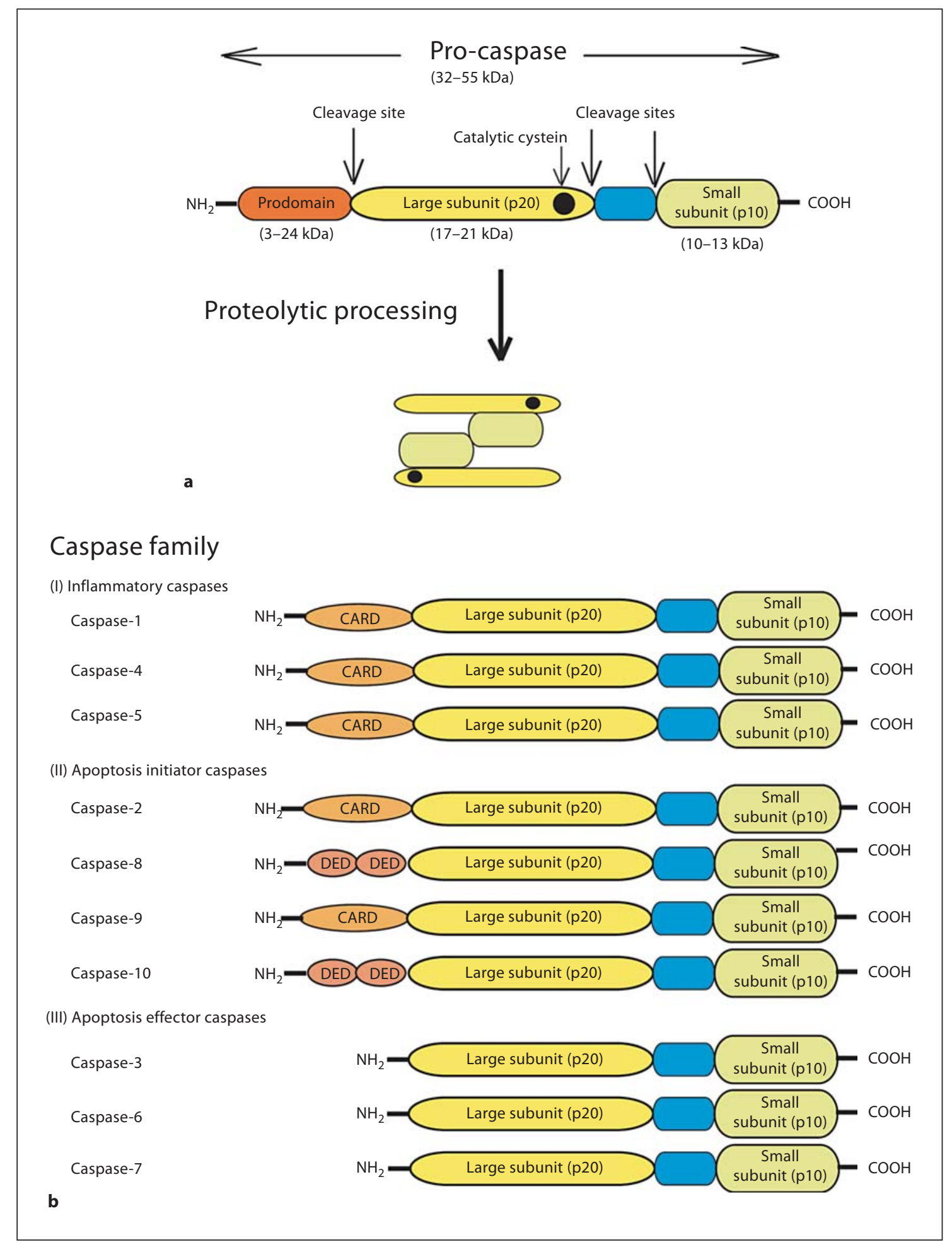

Fig. 1. The caspase family. a Schematic representation of structural features of human caspases and their proteolytic processing. b Alignment of human caspases. 
members of the tumor necrosis factor receptor superfamily, such as TNFR1 or CD95 [4]. Caspase-9, on the other hand, is the canonical caspase in the intrinsic mitochondrial pathway of apoptosis [5]. Following release of cytochrome $\mathrm{c}$ and dATP from the mitochondria, Apaf1 complexes with cytochrome $c$. This results in the recruitment and proteolytic activation of pro-caspase- 9 which in turn activates caspase-3, -6 and -7 [6]. Caspase-3, along with caspase- 6 and -7 , are apoptotic effector caspases [7] and possess a short (20- to 30 -amino acid) N-terminal prodomain. They can cleave a multitude of substrates including structural components of the cytoskeleton, nuclear proteins, protein kinases, cell cycle proteins, or DNA metabolism and repair proteins [reviewed in ref. 8]. Therefore, apoptotic effector caspases are responsible for the 'programmed' destruction of a cell.

The final category of caspases constitutes the inflammatory caspases, which includes human caspase-1, -4, -5 and -12 and murine caspase- $-1,-11$ and -12 [reviewed in ref. 9]. These caspases possess a single CARD at the $\mathrm{N}$ terminus and, as their name suggests, play an important function in initiating inflammatory immune responses. The inflammatory caspases of humans, chimpanzees, monkeys and rodents share significant structural homology and are organized in a single gene locus [9]. While human and mouse caspase- 1 is highly conserved, human caspase- 4 and caspase- 5 have been suggested to originate from a duplication of caspase-11 [10]. Caspase- 11 is therefore the murine orthologue of human caspase- 4 and -5 . Caspase-1, formerly known as interleukin (IL)-1 $\beta$-converting enzyme (ICE), was the first mammalian caspase to be described [11]. This caspase was shown to proteolytically convert the inactive precursor of the $31-\mathrm{kDa}$ IL$1 \beta$ cytokine into its $17-\mathrm{kDa}$ biologically active form, an important step in the initiation of inflammatory responses [11]. In this review, the latest advances in our understanding of the activation, function and regulation of the inflammatory caspases are discussed, with particular focus on caspase-1, the best characterized inflammatory caspase to date. In addition, clinical implications of deregulated inflammatory caspase responses are explored, highlighting their important role in human health and disease.

\section{Activation of Inflammatory Caspases}

As mentioned, in most cases caspases undergo proteolytic processing to become active proteases. Major advances in our understanding of inflammatory caspase activation came with the discovery of the inflammasome, a large protein complex that activates pro-caspase- $1[1$, 12]. The inflammasome consists of three major components: (1) a receptor such as a NOD-like receptor (NLR), which acts as an intracellular sensor and induces complex formation; (2) in most cases the adaptor protein ASC (apoptosis speck-like protein containing a CARD), which recruits pro-caspase-1 to the complex through homotypic CARD interactions, and (3) pro-caspase- 1 , which is auto-proteolytically cleaved, resulting in the generation of active caspase-1 homodimers [1, 12] (fig. 2).

To date, the NLR family consists of 22 human receptors that have been classified according to a common domain structure. This structure consists of a C-terminal leucine-rich repeat (LRR) domain, presumably involved in direct or indirect ligand sensing, a NACHT domain that allows oligomerization, and an $\mathrm{N}$-terminal effector domain that transduces downstream signaling events. NLRs are further classified into subfamilies based on their downstream function and whether their N-terminal effector domain consists of a CARD, a pyrin (PYD) or a baculovirus inhibitor of apoptosis repeat (BIR) domain $[1,13]$. Accordingly, the nucleotide-binding oligomerization domain (NOD) subfamily members possess an N-terminal CARD and induce a RIP2-dependent signaling cascade ultimately leading to the activation of $\mathrm{NF \kappa B}$ and potent cytokine expression $[1,13,14]$. Conversely, the nucleotide-binding oligomerization domain, leucine-rich repeat and pyrin domain-containing (NLRP) subfamily members contain an $\mathrm{N}$-terminal PYD. While the function of several NLRPs is still elusive, the bestcharacterized NLRPs will be discussed later. Despite containing an N-terminal CARD, NLRC4 (also known as IPAF) is functionally more closely related to the NLRP subfamily than to the NOD subfamily, as it has been shown to form inflammasomes. Finally, NAIP is unique among the NLRs, as it contains three N-terminal BIR domains. Several studies showed that NAIP is able to restrict Legionella growth in macrophages [15-17], however, it is unclear whether this involves caspase-1 activation [18].

While the function of most NLRPs remains elusive, NLRP1, NLRP3 and the NLRP-related protein, NLRC4, have been extensively characterized and are known to form inflammasomes that activate pro-caspase-1 [14]. NLRP3 requires the adaptor protein ASC to recruit and activate pro-caspase-1, whereas NLRP1 and NLRC4 also seem to be able to recruit caspase-1 directly through homotypic CARD interactions, independently of ASC [1]. Furthermore, in addition to caspase-1, other caspases 
Fig. 2. Activators and inhibitors of caspase-1. Several factors can modulate the activation of caspase-1. Activators are largely comprised of inflammasome scaffolding proteins of the NOD-like receptor (NLR) family such as NLRP3, NLRP1 and NLRC4. In response to microbial products or danger signals, these scaffolding molecules recruit caspase-1 into a macromolecular complex and result in its activation. Inhibitors of caspase-1 include CrmA, PI-9 and the CARD-only proteins, COP, INCA and ICEBERG. More recently, caspase-12 was identified as an additional potent natural inhibitor of caspase-1.

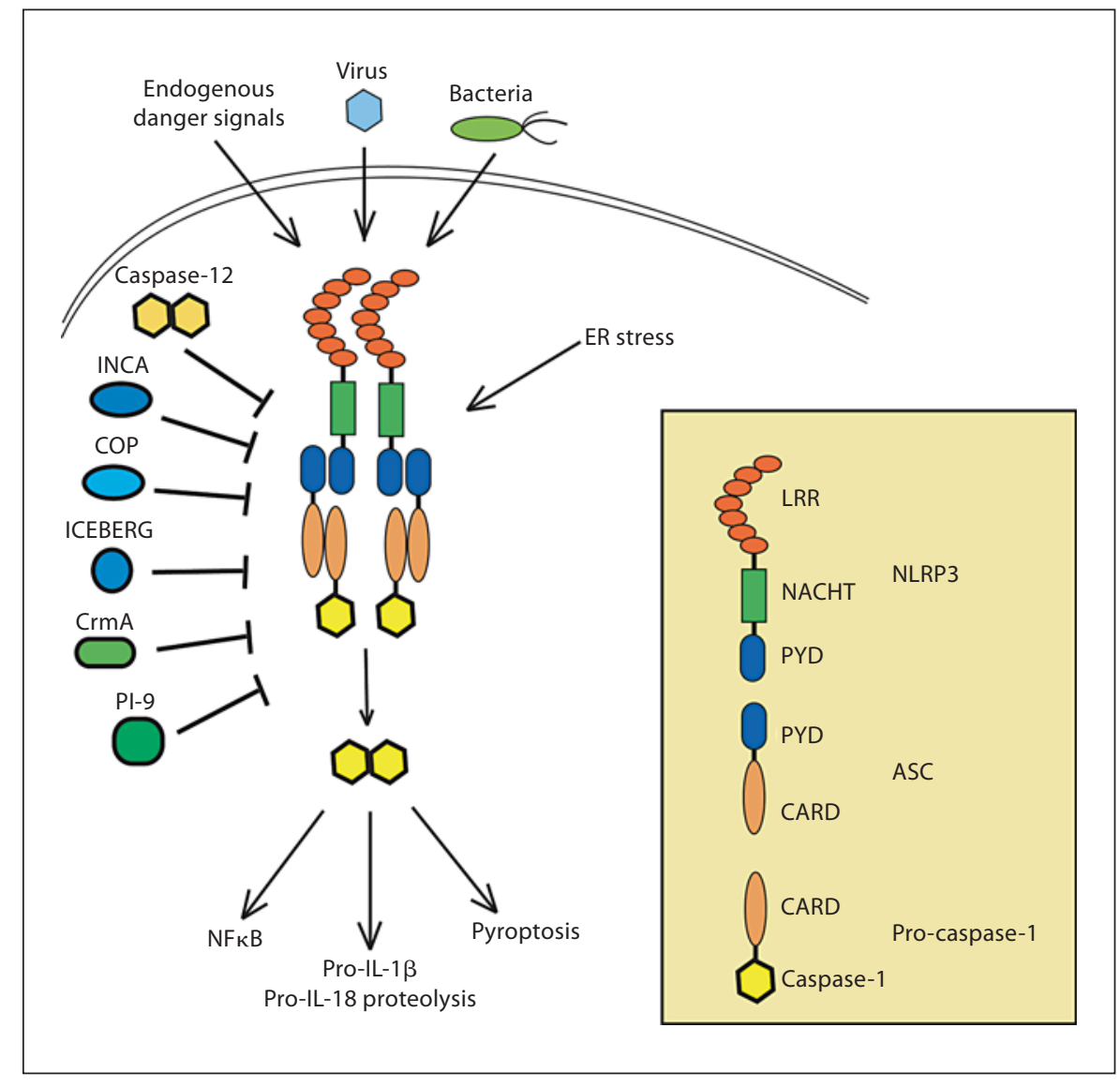

might be recruited to the inflammasome complex. In the case of the NLRP1 inflammasome, recruitment of caspase-5 was shown to take place [12]. More recently, AIM2 (absent in melanoma 2) was described as an inflammasome-forming protein [19-22]. Similar to NLRP3, AIM2 contains a PYD domain and is able to form an inflammasome consisting of ASC and pro-caspase-1 following intracellular DNA stimulation.

NLRP3 is induced to form an inflammasome and activate pro-caspase-1 by a wide variety of chemically and biologically unrelated PAMPs (pathogen-associated molecular patterns) and DAMPs (danger-associated molecular patterns) [1]. Such diversity in activating stimuli beckons just how inflammasome complexes become activated. Although this has been the subject of intense and ongoing investigation, the exact mechanism remains elusive. The presence of an LRR domain implies that NLRP3 may bind its ligands directly, in a mechanism analogous to Toll-like receptors (TLRs). Yet no evidence in support of this hypothesis has been published to date. Therefore, an alternative hypothesis has been put forward whereby
NLRP3 is proposed to detect an intermediate molecule that is generated by a common mechanism elicited by all NLRP3 activators. In line with this, it has been shown that potassium efflux is essential for NLRP3 activation [23]. In an evolutionary sense, the release of potassium may represent a danger signal, as some bacteria express pore-forming toxins, such as nigericin, leading to the release of potassium $[24,25]$. However, it remains unclear whether potassium efflux itself represents an NLRP3 stimulus or whether low intracellular potassium provides a favorable environment for inflammasome assembly following the appearance of an as yet undefined primary stimulus. More recently, it was shown that NLRP3 activation by amyloid- $\beta$ or crystals such as silica and aluminum salts depends on lysosomal leakage and the release of the lysosomal protease cathepsin B into the cytosol [26]. In this model, cathepsin B might induce a signaling cascade eventually leading to inflammasome formation. Reactive oxygen species might represent another common NLRP3 activator, which is induced by a range of PAMPs and DAMPs. Indeed, inhibition of reactive oxy- 
gen species production with chemical inhibitors, as well as shRNA against proteins of the NADPH oxidase complex, leads to a reduction in pro-caspase- 1 activation and mature IL-1 $\beta$ production $[27,28]$. Clearly, the mode of inflammasome activation could be stimulus as well as cell type specific. Further research is thus required to elucidate the mechanisms underlying the activation of NLRP3, and other NLR, in order to fully understand inflammasome formation and inflammatory caspase activation.

\section{Downstream Functions of Inflammatory Caspases}

\section{Cytokine Activation}

The best-defined function of active caspase- 1 is proteolytic processing of inflammatory cytokines, pro-IL$1 \beta$ and pro-IL-18, to their biologically active forms [1]. By controlling the signaling of these cytokines, caspase-1 greatly influences innate immunity and inflammation. In addition to pro-IL-1 $\beta$ and pro-IL-18 activation, further inflammatory functions of caspase- 1 are beginning to emerge $[1,29-31]$. These include the regulation of unconventional protein secretion. A study by Keller et al. [32] describes the requirement of caspase-1 activation for the secretion of several cytokines, such as IL-1 $\alpha$ and FGF2. Via homotypic CARD interactions, caspase-1 was shown to interact with the serine/threonine kinase RIP2 to directly activate NFкB [33]. Furthermore, evidence suggests that competition exists between the inflammasome adaptor molecule ASC and RIP2 for caspase-1 interaction, resulting in a shift towards either inflammasome formation or $\mathrm{NF \kappa B}$ activation, depending on the ratio of ASC to RIP2 [34]. It is important to note, however, that caspase-1-dependent NFKB activation has only been demonstrated in vitro and awaits confirmation in vivo.

\section{Pyroptosis}

While the importance of caspases in apoptosis has been extensively highlighted, caspases are also implicated in pyroptosis, a recently described pathway of programmed cell death that is distinct from apoptosis [31]. Unlike apoptosis which is silent with respect to inflammation, pyroptosis is characterized by rapid plasma membrane rupture, release of danger signals into the extracellular milieu and subsequent induction of inflammatory immune responses [35]. Furthermore, unlike intrinsic apoptosis, pyroptosis is dependent on caspase-1 activation, occurs independently of caspase- $3,-6$ and -8 , and does not require the breakdown of mitochondrial integrity and subsequent release of cytochrome c [31, 36]. Upon infection with particular pathogens, cell death was shown to be redirected from apoptosis to pyroptosis, which might represent a host mechanism to combat infection, by inducing increased inflammation [37]. Although a requirement for caspase- 1 activation was demonstrated, events downstream of caspase-1 are still unknown. Therefore, it is still unclear how caspase-1 induces programmed cell death distinct from apoptosis.

\section{Endoplasmic Reticulum Stress}

Endoplasmic reticulum (ER) stress can arise from protein accumulation inside the ER or excessive protein trafficking through the ER, e.g. during viral infection. Activation of inflammatory caspase-12 is a well-established hallmark of ER stress. More recently, activation of caspase- 4 as a result of ER stress was also demonstrated [38]. In accordance with these results, suppression of caspase4 or -12 activation was shown to abrogate ER-stress-induced apoptosis, possibly linking these caspases to the pathogenesis of neurodegenerative disorders [38-40]. However, the function of inflammatory caspases in ER stress remains under debate, as several recent studies have challenged the aforementioned evidence [41-43].

\section{Regulation of Inflammatory Caspases}

In order to control the potent inflammatory responses induced by inflammatory caspases, stringent regulation must be in place. Several mechanisms have been elucidated so far. Of these, three proteins were identified that directly inhibit the enzymatic activity of caspase-1 [4448]. These proteins, known as COP (CARD only protein), INCA (inhibitory CARD) and ICEBERG (also known as CARD18), are encoded in the same gene locus as human caspase- $1,-4$ and -5 . Their structure is highly analogous to the C-terminal CARD of inflammatory caspases, thus enabling these proteins to directly inhibit caspase-1 via competitive homotypic CARD interactions. However, little is known about the regulation and expression of these proteins in a physiological context. Regulating caspase-1 activation through a similar mechanism as COPs, pyrin and POP (pyrin only protein) 1 and 2 interact with the pyrin domains of ASC and other NLRPs, thereby inhibiting inflammasome assembly and consequently caspase- 1 activation [49-51]. In addition to COPs and POPs, several other endogenous inhibitors of inflammatory caspases with distinct mode of actions have been de- 
scribed. PI-9 (serpin protease inhibitor 9) was shown to negatively regulate caspase- $1,-4$ and -8 through binding to the activation loop of these caspases $[52,53]$ (fig. 2). More recently, the anti-apoptotic proteins $\mathrm{Bcl}-2$ and $\mathrm{Bcl}-$ $\mathrm{X}_{\mathrm{L}}$ were shown to interfere with NLRP1 oligomerization, possibly due to inhibiting ATP binding to NLRP1 [54].

Alternative splicing, tissue-specific distribution and gene induction by inflammatory stimuli add a layer of complexity to endogenous mechanisms of inflammatory caspase regulation. In most tissues and cells other than monocytes, macrophages and dendritic cells, low-level inflammatory caspase expression likely serves as a safeguard for activation under legitimate immune threat [55]. Further to this, inflammatory caspase expression can be induced upon exposure to IFN $\gamma$, TNF, LPS and other bacterial products [43, 55-61].

In addition to the endogenous regulatory mechanisms discussed above, pathogens have also evolved strategies to evade inflammatory caspase responses. The cowpox virus protein, CrmA (cytokine response modifier A), is one such example. CrmA inhibits caspase-1 and subsequent IL-1 $\beta$ proteolysis, thus suppressing the inflammatory response during cowpox virus infection [62] (fig. 2). Similarly, the poxviral gene product M13L-PYD is able to inhibit caspase-1 activation through homotypic PYDPYD interactions with ASC [63]. Finally, mycobacteria have been shown to inhibit caspase-1 activation. This represents one of the mechanisms by which mycobacteria achieve immune suppression and parasitize host macrophages [64].

A recent publication indicates the existence of crosstalk between TLR signaling and caspase-1. While TLR signaling induces pro-IL- $1 \beta$ production, NLR signaling is required for caspase- 1 activation and mature IL- $1 \beta$ secretion. Miggin et al. [65] present data showing interaction between Mal (MyD88 adaptor-like), an adaptor molecule used by TLR 2 and TLR4, and caspase-1. This physical interaction leads to the cleavage of Mal and, subsequently, the inhibition of TLR2 and TLR4 signaling. These results thus imply the existence of a negative feedback loop, whereby the activation of caspase-1 can terminate, among others, pro-IL-1 $\beta$ expression.

Finally, it could be shown that abrogation of NFKB signaling in neutrophils and macrophages results in increased susceptibility to endotoxin shock due to elevated IL-1 $\beta$ levels in the serum of these mice [66]. These results suggest an inhibitory effect of NFKB signaling on pro-IL$1 \beta$ processing possibly through the induction of inflammasome/caspase inhibitors. These data are supported by recent findings by our group showing that effector and

Inflammatory Caspases in Innate

Immunity and Inflammation memory T cells can efficiently suppress macrophage caspase-1 activation in response to NLRP1 and NLRP3 stimuli in an antigen-dependent way. The same effect is indeed achieved by incubating the antigen-presenting cells with ligands of the TNF family expressed on activated T cells, such as the potent NFкB activator CD40L. This finding infers the existence of a cross-talk mechanism from the adaptive to the innate immune cells, whereby the quality of the inflammatory mediators produced by the latter can be controlled, avoiding inadequate responses.

\section{Clinical Implications of Deregulated Inflammatory Caspase Responses}

The most important function of inflammatory caspases is to protect the organism against intrinsic and extrinsic danger and to induce inflammation when a protective inflammatory response is required. Inflammatory caspases mediate responses to danger signals such as ATP [25], monosodium urate [68] or UVB irradiation [69], and aid in the clearance of many pathogens including Salmonella [70], Shigella [71], Legionella (together with caspase-7) [72] and Candida albicans [73]. In support of this, caspase- 1 has been described to cleave enzymes involved in glycolosis, thereby regulating metabolism during infections [74]. However, as discussed below, inappropriate activation of caspase-1 may be detrimental.

Overactivation of caspase- 1 due to missense mutations in the NACHT domain of NLRP3, the domain responsible for oligomerization, can cause hereditary autoinflammatory diseases, such as familial cold urticaria, Muckle-Wells syndrome and neonatal-onset multisystem inflammatory disease (NOMID; also known as chronic infantile neurologic, cutaneous, articular syndrome, CINCA) [75]. These disorders are clinically characterized by periodic fever accompanied by skin rashes, amyloid depositions and, in the case of NOMID, neurological complications and hearing impairment. As macrophages from these patients display spontaneous processing and secretion of IL-1 $\beta$ [76], treatment of patients with IL-1 receptor antagonists dramatically diminishes disease severity and progression by blocking the downstream effects of IL-1 $\beta$, thus counteracting the effects of increased caspase-1 activity [77, 78].

Familial Mediterranean fever is an autosomal-recessive disease with similar clinical symptoms to MuckleWells syndrome, characterized by mutations in the protein known as pyrin. However, the impact of pyrin muta- 
tions on inflammasomes is controversial. On the one hand, mutations in the C-terminal part of pyrin can enable the protein to interact with the PYD of ASC, blocking the recruitment of ASC to the inflammasome and thereby diminishing caspase-1 activation [79]. Recent data, however, describe a direct interaction between the SPRY domain of pyrin with NLRP3, leading to the assembly of the inflammasome complex and enhanced IL$1 \beta$ secretion $[80,81]$.

Non-hereditary diseases can also be exacerbated by deregulated inflammatory caspase responses. Polymorphisms in human caspase-12, resulting in the synthesis of a full-length caspase-12 zymogen (caspase-12L), are strongly associated with increased susceptibility to severe infections such as bacterial-induced sepsis. An inhibitory effect of caspase-12L on caspase- 1 activation was suggested as the underlying mechanism for this observation [43]. Deregulated caspase-1 responses are also linked to cardiovascular disease [82], inflammatory bowel disease [83], psoriasis [84] and neurological diseases such as Huntington's disease [85] (table 1). However, the actual impact of caspase- 1 on the pathogenesis of these diseases requires further investigation.

\section{Conclusion}

In addition to their well-characterized role in apoptosis, caspases have emerged as critical mediators of innate immunity and inflammatory responses. In accordance with their apoptotic counterparts, the so-called inflammatory caspases are produced as inactive zymogens that require cleavage to generate their active, proteolytic forms. Caspase-1 represents the best-studied inflammatory caspase to date. Activation of caspase-1, and probably of other inflammatory caspases, requires assembly of large cytosolic protein complexes termed inflammasomes that are induced by a growing number of microbial and chemical environmental stimuli. Once activated, caspase- 1 cleaves pro-IL-1 $\beta$ and pro-IL-18 to their biologically active forms, initiating a potent inflammatory response. In addition, inflammatory caspases have recently been implicated in pyroptosis and, albeit controversial, in ER stress responses.

As inflammatory caspases are important regulators of innate immune responses, their activity is controlled by stringent regulatory mechanisms. Such mechanisms include endogenous inhibitory proteins that compete for pro-caspase- 1 binding and inhibit caspase- 1 activation, as well as tissue-specific and inflammation-inducible
Table 1. Diseases with possible involvement of inflammasomes or inflammatory caspases

Hereditary syndromes with known site of mutations

Muckle-Wells syndrome NLRP3 [86]

Familial cold autoinflammatory syndrome/urticaria $\quad$ NLRP3 [86]

Neonatal-onset multisystem inflammatory disease (NOMID, CINCA)

Familial Mediterranean fever

Pyogenic arthritis, pyoderma gangrenosum and acne syndrome

NLRP3 [75] pyrin [79]

PSTPIP1 [87]

Diseases with involvement of inflammatory caspases or their effectors

Gout

Pseudogout

Contact hypersensitivity

Vitiligo

Malaria

Hydatidiform moles

Crohn's disease (SNP)

Type 2 diabetes

Hypertension

Fever syndromes

Brain injury

Psoriasis

Huntington's disease

Sjögren's syndrome

Legionella pneumophila infection

Sepsis

Epidermal water loss and UV damage

NLRP3 [68]
NLRP3 [68]
NLRP3 [88, 89]
NLRP1 [90]
NLRP3 [67]
NLRP7 [91]
NLRP3 [99]
IL-13 [92]
NLRP3 [93]
NLRP12 [94]
NLRP1 [95]
caspase-1 [84]
caspase-1 [85]
caspase-1 [96]
caspase-7 [72]
caspase-12 [97]
caspase-14 [98]

gene expression patterns. Failure to sufficiently regulate inflammatory caspase activation can manifest in severe autoinflammatory diseases such as hereditary fever syndromes, or dramatically increase susceptibility to bacterial sepsis.

Although the field of innate immunity and caspase-1 activation in particular has made enormous progress, the exact mechanism of inflammasome activation and possibly new functions of inflammatory caspases need to be addressed to understand their suitability as putative targets for the treatment of inflammatory diseases.

\section{Acknowledgments}

We thank Prof. Tschopp and his laboratory for inspiring discussions. This work was supported by the German Research Foundation DFGYA-182/1-1 (A.S.Y.), the National Health and Medical Research Council of Australia (M.C.D.) and the Apo-Sys Consortium of the European Union (S.K.D.). 


\section{References}

1 Martinon F, Mayor A, Tschopp J: The inflammasomes: guardians of the body. Annu Rev Immunol 2009;27:229-265.

$\checkmark 2$ Boatright KM, Renatus M, Scott FL, Sperandio S, Shin H, Pedersen IM, Ricci JE, Edris WA, Sutherlin DP, Green DR, Salvesen GS: A unified model for apical caspase activation. Mol Cell 2003;11:529-541.

-3 Yuan J, Shaham S, Ledoux S, Ellis HM, Horvitz HR: The C. elegans cell death gene ced-3 encodes a protein similar to mammalian interleukin-1 beta-converting enzyme. Cell 1993; 75:641-652.

4 Muzio M, Chinnaiyan AM, Kischkel FC, O’Rourke K, Shevchenko A, Ni J, Scaffidi C, Bretz JD, Zhang M, Gentz R, Mann M, Krammer PH, Peter ME, Dixit VM: FLICE, a novel FADD-homologous ICE/CED-3-like protease, is recruited to the CD95 (Fas/APO1) death-inducing signaling complex. Cell 1996;85:817-827.

5 Gross A, McDonnell JM, Korsmeyer SJ: Bcl-2 family members and the mitochondria in apoptosis. Genes Dev 1999;13:1899-1911.

$\checkmark 6$ Li P, Nijhawan D, Budihardjo I, Srinivasula SM, Ahmad M, Alnemri ES, Wang X: Cytochrome $\mathrm{c}$ and dATP-dependent formation of Apaf-1/caspase-9 complex initiates an apoptotic protease cascade. Cell 1997;91:479489.

7 Deveraux QL, Takahashi R, Salvesen GS, Reed JC: X-linked IAP is a direct inhibitor of cell-death proteases. Nature 1997;388:300304.

$>8$ Chowdhury I, Tharakan B, Bhat GK: Caspases - an update. Comp Biochem Physiol B Biochem Mol Biol 2008;151:10-27.

$\checkmark 9$ Kersse K, Vanden Berghe T, Lamkanfi M, Vandenabeele P: A phylogenetic and functional overview of inflammatory caspases and caspase-1-related CARD-only proteins. Biochem Soc Trans 2007;35:1508-1511.

10 Martinon F, Tschopp J: Inflammatory caspases: linking an intracellular innate immune system to autoinflammatory diseases. Cell 2004;117:561-574.

-11 Black RA, Kronheim SR, Merriam JE, March CJ, Hopp TP: A pre-aspartate-specific protease from human leukocytes that cleaves prointerleukin-1 beta. J Biol Chem 1989;264: 5323-5326.

12 Martinon F, Burns K, Tschopp J: The inflammasome: a molecular platform triggering activation of inflammatory caspases and processing of proIL-beta. Mol Cell 2002;10: 417-426.

-13 Dostert C, Meylan E, Tschopp J: Intracellular pattern-recognition receptors. Adv Drug Deliv Rev 2008;60:830-840.

-14 Meylan E, Tschopp J, Karin M: Intracellular pattern recognition receptors in the host response. Nature 2006;442:39-44.
15 Diez E, Lee SH, Gauthier S, Yaraghi Z, Tremblay M, Vidal S, Gros P: Bircle is the gene within the Lgn1 locus associated with resistance to Legionella pneumophila. Nat Genet 2003;33:55-60.

16 Ren T, Zamboni DS, Roy CR, Dietrich WF, Vance RE: Flagellin-deficient Legionella mutants evade caspase-1- and Naip5-mediated macrophage immunity. PLoS Pathog 2006;2:e18.

17 Wright EK, Goodart SA, Growney JD, Hadinoto V, Endrizzi MG, Long EM, Sadigh K, Abney AL, Bernstein-Hanley I, Dietrich WF: Naip5 affects host susceptibility to the intracellular pathogen Legionella pneumophila. Curr Biol 2003;13:27-36.

18 Lamkanfi M, Amer A, Kanneganti TD, Munoz-Planillo R, Chen G, Vandenabeele P Fortier A, Gros P, Nunez G: The Nod-like receptor family member Naip5/Bircle restricts Legionella pneumophila growth independently of caspase-1 activation. J Immunol 2007;178:8022-8027.

19 Burckstummer T, Baumann C, Bluml S, Dixit E, Durnberger G, Jahn H, Planyavsky M, Bilban M, Colinge J, Bennett KL, SupertiFurga G: An orthogonal proteomic-genomic screen identifies AIM2 as a cytoplasmic DNA sensor for the inflammasome. Nat Im munol 2009; 10:266-272.

20 Fernandes-Alnemri T, Yu JW, Datta P, Wu J, Alnemri ES: AIM2 activates the inflammasome and cell death in response to cytoplas mic DNA. Nature 2009;458:509-513.

21 Hornung V, Ablasser A, Charrel-Dennis M, Bauernfeind F, Horvath G, Caffrey DR, Latz E, Fitzgerald KA: AIM2 recognizes cytosolic dsDNA and forms a caspase-1-activating inflammasome with ASC. Nature 2009;458: 514-518.

22 Roberts TL, Idris A, Dunn JA, Kelly GM, Burnton CM, Hodgson S, Hardy LL, Garceau V, Sweet MJ, Ross IL, Hume DA, Stacey KJ: HIN-200 proteins regulate caspase activation in response to foreign cytoplasmic DNA. Science 2009;323:1057-1060.

23 Petrilli V, Papin S, Dostert C, Mayor A, Martinon F, Tschopp J: Activation of the NALP3 inflammasome is triggered by low intracellular potassium concentration. Cell Death Differ 2007; 14:1583-1589.

24 McIntire CR, Yeretssian G, Saleh M: Inflammasomes in infection and inflammation. Apoptosis 2009; 14:522-535.

25 Mariathasan S, Weiss DS, Newton K, McBride J, O’Rourke K, Roose-Girma M, Lee WP, Weinrauch Y, Monack DM, Dixit VM: Cryopyrin activates the inflammasome in response to toxins and ATP. Nature 2006; 440:228-232.
26 Hornung V, Bauernfeind F, Halle A, Samstad EO, Kono H, Rock KL, Fitzgerald KA, Latz E: Silica crystals and aluminum salts activate the NALP3 inflammasome through phagosomal destabilization. Nat Immunol 2008;9: 847-856.

27 Dostert C, Petrilli V, Van Bruggen R, Steele C, Mossman BT, Tschopp J: Innate immune activation through NALP3 inflammasome sensing of asbestos and silica. Science 2008; 320:674-677.

28 Cassel SL, Eisenbarth SC, Iyer SS, Sadler JJ, Colegio OR, Tephly LA, Carter AB, Rothman PB, Flavell RA, Sutterwala FS: The NALP3 inflammasome is essential for the development of silicosis. Proc Natl Acad Sci USA 2008;105:9035-9040.

29 Scott AM, Saleh M: The inflammatory caspases: guardians against infections and sepsis. Cell Death Differ 2007;14:23-31.

-30 Martinon F, Tschopp J: Inflammatory caspases and inflammasomes: master switches of inflammation. Cell Death Differ 2007;14: 10-22.

31 Bergsbaken T, Fink SL, Cookson BT: Pyroptosis: host cell death and inflammation. Nat Rev Microbiol 2009;7:99-109.

32 Keller M, Ruegg A, Werner S, Beer HD: Active caspase- 1 is a regulator of unconventional protein secretion. Cell 2008;132:818-831.

33 Lamkanfi M, Kalai M, Saelens X, Declercq W, Vandenabeele P: Caspase-1 activates nuclear factor of the kappa-enhancer in B cells independently of its enzymatic activity. J Biol Chem 2004;279:24785-24793.

-34 Sarkar A, Duncan M, Hart J, Hertlein E, Guttridge DC, Wewers MD: ASC directs $\mathrm{NF}-\kappa \mathrm{b}$ activation by regulating receptor interacting protein-2 (RIP2) caspase-1 interactions. J Immunol 2006;176:4979-4986.

35 Fink SL, Cookson BT: Caspase-1-dependent pore formation during pyroptosis leads to osmotic lysis of infected host macrophages. Cell Microbiol 2006;8:1812-1825.

-36 Cervantes J, Nagata T, Uchijima M, Shibata K, Koide Y: Intracytosolic Listeria monocytogenes induces cell death through caspase-1 activation in murine macrophages. Cell Microbiol 2008; 10:41-52.

37 Bergsbaken T, Cookson BT: Macrophage activation redirects Yersinia-infected host cell death from apoptosis to caspase-1-dependent pyroptosis. PLoS Pathog 2007;3:e161.

$\checkmark 38$ Hitomi J, Katayama T, Eguchi Y, Kudo T, Taniguchi M, Koyama Y, Manabe T, Yamagishi S, Bando Y, Imaizumi K, Tsujimoto Y, Tohyama M: Involvement of caspase-4 in endoplasmic reticulum stress-induced apoptosis and $\mathrm{A} \beta$-induced cell death. J Cell Biol 2004; 165:347-356.

-39 Nakagawa T, Zhu H, Morishima N, Li E, Xu J, Yankner BA, Yuan J: Caspase-12 mediates endoplasmic-reticulum-specific apoptosis and cytotoxicity by amyloid-beta. Nature 2000;403:98-103. 
-40 Hetz C, Russelakis-Carneiro M, Maundrell $\mathrm{K}$, Castilla J, Soto C: Caspase-12 and endoplasmic reticulum stress mediate neurotoxicity of pathological prion protein. EMBO J 2003;22:5435-5445.

- 41 Obeng EA, Boise LH: Caspase-12 and caspase- 4 are not required for caspase-dependent endoplasmic reticulum stress-induced apoptosis. J Biol Chem 2005;280:2957829587.

-42 Di Sano F, Ferraro E, Tufi R, Achsel T, Piacentini M, Cecconi F: Endoplasmic reticulum stress induces apoptosis by an apoptosome-dependent but caspase 12-independent mechanism. J Biol Chem 2006;281:26932700.

43 Saleh M, Mathison JC, Wolinski MK, Bensinger SJ, Fitzgerald P, Droin N, Ulevitch RJ, Green DR, Nicholson DW: Enhanced bacterial clearance and sepsis resistance in caspase-12-deficient mice. Nature 2006;440: 1064-1068.

-44 Razmara M, Srinivasula SM, Wang L, Poyet JL, Geddes BJ, DiStefano PS, Bertin J, Alnemri ES: CARD-8 protein, a new CARD family member that regulates caspase-1 activation and apoptosis. J Biol Chem 2002;277:1395213958.

45 Lee SH, Stehlik C, Reed JC: Cop, a caspase recruitment domain-containing protein and inhibitor of caspase-1 activation processing. J Biol Chem 2001;276:34495-34500.

- 46 Humke EW, Shriver SK, Starovasnik MA, Fairbrother WJ, Dixit VM: ICEBERG: a novel inhibitor of interleukin-1 $\beta$ generation. Cell 2000;103:99-111.

-47 Druilhe A, Srinivasula SM, Razmara M, Ahmad M, Alnemri ES: Regulation of IL- $1 \beta$ generation by Pseudo-ICE and ICEBERG, two dominant negative caspase recruitment domain proteins. Cell Death Differ 2001;8: 649-657.

48 Lamkanfi M, Denecker G, Kalai M, D’Hondt K, Meeus A, Declercq W, Saelens X, Vandenabeele P: INCA, a novel human caspase recruitment domain protein that inhibits interleukin-1beta generation. J Biol Chem 2004;279:51729-51738.

49 Stehlik C, Krajewska M, Welsh K, Krajewski S, Godzik A, Reed JC: The PAAD/PYRINonly protein POP1/ASC2 is a modulator of ASC-mediated nuclear-factor-kappa $\beta$ and pro-caspase-1 regulation. Biochem J 2003; 373:101-113.

50 Dorfleutner A, Bryan NB, Talbott SJ, Funya KN, Rellick SL, Reed JC, Shi X, Rojanasakul Y, Flynn DC, Stehlik C: Cellular pyrin domain-only protein 2 is a candidate regulator of inflammasome activation. Infect Immun 2007;75:1484-1492.

-51 Bedoya F, Sandler LL, Harton JA: Pyrin-only protein 2 modulates NF- $\mathrm{\kappa B}$ and disrupts ASC:CLR interactions. J Immunol 2007; 178: 3837-3845.
52 Annand RR, Dahlen JR, Sprecher CA, De Dreu P, Foster DC, Mankovich JA, Talanian RV, Kisiel W, Giegel DA: Caspase-1 (interleukin-1 $\beta$-converting enzyme) is inhibited by the human serpin analogue proteinase inhibitor 9. Biochem J 1999;342:655-665.

53 Young JL, Sukhova GK, Foster D, Kisiel W, Libby P, Schonbeck U: The serpin proteinase inhibitor 9 is an endogenous inhibitor of interleukin $1 \beta$-converting enzyme (caspase-1) activity in human vascular smooth muscle cells. J Exp Med 2000;191:1535-1544.

54 Faustin B, Chen Y, Zhai D, Le Negrate G, Lartigue L, Satterthwait A, Reed JC: Mechanism of Bcl-2 and $\mathrm{Bcl}-\mathrm{X}(\mathrm{L})$ inhibition of NLRP1 inflammasome: loop domain-dependent suppression of ATP binding and oligomerization. Proc Natl Acad Sci USA 2009;106:3935-3940.

55 Watson RW, Rotstein OD, Parodo J, Bitar R, Marshall JC: The IL-1 beta-converting enzyme (caspase-1) inhibits apoptosis of inflammatory neutrophils through activation of IL-1 beta. J Immunol 1998;161:957-962.

56 Lin XY, Choi MS, Porter AG: Expression analysis of the human caspase-1 subfamily reveals specific regulation of the CASP5 gene by lipopolysaccharide and interferon-gamma. J Biol Chem 2000;275:39920-39926.

57 Chawla-Sarkar M, Lindner DJ, Liu YF, Williams BR, Sen GC, Silverman RH, Borden EC: Apoptosis and interferons: role of interferon-stimulated genes as mediators of apoptosis. Apoptosis 2003;8:237-249.

58 Kalai M, Lamkanfi M, Denecker G, Boogmans M, Lippens S, Meeus A, Declercq W, Vandenabeele P: Regulation of the expression and processing of caspase-12. J Cell Biol 2003;162:457-467.

59 Kobori M, Yang Z, Gong D, Heissmeyer V, Zhu H, Jung YK, Gakidis MA, Rao A, Sekine T, Ikegami F, Yuan C, Yuan J: Wedelolactone suppresses LPS-induced caspase-11 expression by directly inhibiting the IKK complex. Cell Death Differ 2004;11:123-130.

60 Schauvliege R, Vanrobaeys J, Schotte P, Beyaert R: Caspase-11 gene expression in response to lipopolysaccharide and interferongamma requires nuclear factor-kappa B and signal transducer and activator of transcription (STAT) 1. J Biol Chem 2002;277:4162441630.

61 Hur J, Kim SY, Kim H, Cha S, Lee MS, Suk K: Induction of caspase-11 by inflammatory stimuli in rat astrocytes: lipopolysaccharide induction through p38 mitogen-activated protein kinase pathway. FEBS Lett 2001;507: 157-162.

62 Ray CA, Black RA, Kronheim SR, Greenstreet TA, Sleath PR, Salvesen GS, Pickup DJ: Viral inhibition of inflammation: cowpox virus encodes an inhibitor of the interleukin1 beta converting enzyme. Cell 1992;69:597604.
63 Johnston JB, Barrett JW, Nazarian SH, Goodwin M, Ricciuto D, Wang G, McFadden G: A poxvirus-encoded pyrin domain protein interacts with ASC-1 to inhibit host inflammatory and apoptotic responses to infection. Immunity 2005;23:587-598.

64 Master SS, Rampini SK, Davis AS, Keller C, Ehlers S, Springer B, Timmins GS, Sander P, Deretic V: Mycobacterium tuberculosis prevents inflammasome activation. Cell Host Microbe 2008;3:224-232.

-65 Miggin SM, Palsson-McDermott E, Dunne A, Jefferies C, Pinteaux E, Banahan K, Murphy C, Moynagh P, Yamamoto M, Akira S, Rothwell N, Golenbock D, Fitzgerald KA, O'Neill LA: NF- $\kappa$ B activation by the Toll-IL1 receptor domain protein MyD88 adapterlike is regulated by caspase- 1 . Proc Natl Acad Sci USA 2007;104:3372-3377.

66 Greten FR, Arkan MC, Bollrath J, Hsu LC, Goode J, Miething C, Goktuna SI, Neuenhahn M, Fierer J, Paxian S, Van Rooijen N, Xu Y, O'Cain T, Jaffee BB, Busch DH, Duyster J, Schmid RM, Eckmann L, Karin M: NF$\kappa \mathrm{B}$ is a negative regulator of IL- $1 \beta$ secretion as revealed by genetic and pharmacological inhibition of IKKß. Cell 2007;130:918-931.

67 Guarda G, Dostert C, Staehli F, Cabalzar K, Castillo R, Tardivel A, Schneider P, Tschopp $\mathrm{J}$ : T cells dampen innate immune responses through inhibition of NLRP1 and NLRP3 inflammasomes. Nature 2009;460:269-273.

-68 Martinon F, Petrilli V, Mayor A, Tardivel A, Tschopp J: Gout-associated uric acid crystals activate the NALP3 inflammasome. Nature 2006;440:237-241.

-69 Feldmeyer L, Keller M, Niklaus G, Hohl D, Werner S, Beer HD: The inflammasome mediates UVB-induced activation and secretion of interleukin- $1 \beta$ by keratinocytes. Curr Biol 2007; 17:1140-1145.

70 Lara-Tejero M, Sutterwala FS, Ogura Y, Grant EP, Bertin J, Coyle AJ, Flavell RA, Galan JE: Role of the caspase-1 inflammasome in Salmonella typhimurium pathogenesis. J Exp Med 2006;203:1407-1412.

71 Sansonetti PJ, Phalipon A, Arondel J, Thirumalai $\mathrm{K}$, Banerjee S, Akira S, Takeda K, Zychlinsky A: Caspase-1 activation of IL-1 $\beta$ and IL-18 are essential for Shigella flexneriinduced inflammation. Immunity 2000;12: 581-590.

72 Akhter A, Gavrilin MA, Frantz L, Washington S, Ditty C, Limoli D, Day C, Sarkar A, Newland C, Butchar J, Marsh CB, Wewers MD, Tridandapani S, Kanneganti TD, Amer AO: Caspase-7 activation by the NLRC4/ IPAF inflammasome restricts Legionella pneumophila infection. PLoS Pathog 2009;5: e1000361

73 Gross O, Poeck H, Bscheider M, Dostert C, Hannesschlager N, Endres S, Hartmann G, Tardivel A, Schweighoffer E, Tybulewicz V, Mocsai A, Tschopp J, Ruland J: Syk kinase signalling couples to the Nlrp3 inflammasome for anti-fungal host defence. Nature 2009;459:433-436. 
74 Shao W, Yeretssian G, Doiron K, Hussain SN, Saleh M: The caspase-1 digestome identifies the glycolysis pathway as a target during infection and septic shock. J Biol Chem 2007;282:36321-36329.

75 Neven B, Callebaut I, Prieur AM, Feldmann J, Bodemer C, Lepore L, Derfalvi B, Benjaponpitak S, Vesely R, Sauvain MJ, Oertle S, Allen R, Morgan G, Borkhardt A, Hill C, Gardner-Medwin J, Fischer A, de Saint Basile G: Molecular basis of the spectral expression of CIAS1 mutations associated with phagocytic cell-mediated autoinflammatory disorders CINCA/NOMID, MWS, and FCU. Blood 2004;103:2809-2815.

-76 Agostini L, Martinon F, Burns K, McDermott MF, Hawkins PN, Tschopp J: NALP3 forms an IL-1 $\beta$-processing inflammasome with increased activity in Muckle-Wells autoinflammatory disorder. Immunity 2004; 20:319-325.

-77 Hawkins PN, Lachmann HJ, McDermott MF: Interleukin-1-receptor antagonist in the Muckle-Wells syndrome. N Engl J Med 2003; 348:2583-2584.

-78 Hoffman HM, Rosengren S, Boyle DL, Cho JY, Nayar J, Mueller JL, Anderson JP, Wanderer AA, Firestein GS: Prevention of coldassociated acute inflammation in familial cold autoinflammatory syndrome by interleukin-1 receptor antagonist. Lancet 2004; 364:1779-1785.

-79 Chae JJ, Komarow HD, Cheng J, Wood G, Raben N, Liu PP, Kastner DL: Targeted disruption of pyrin, the FMF protein, causes heightened sensitivity to endotoxin and a defect in macrophage apoptosis. Mol Cell 2003; 11:591-604.

-80 Papin S, Cuenin S, Agostini L, Martinon F, Werner S, Beer HD, Grutter C, Grutter M, Tschopp J: The SPRY domain of Pyrin, mutated in familial Mediterranean fever patients, interacts with inflammasome components and inhibits proIL-1 $\beta$ processing. Cell Death Differ 2007;14:1457-1466.

- 81 Yu JW, Wu J, Zhang Z, Datta P, Ibrahimi I, Taniguchi S, Sagara J, Fernandes-Alnemri T, Alnemri ES: Cryopyrin and pyrin activate caspase-1, but not NF- $\kappa$ B, via ASC oligomerization. Cell Death Differ 2006;13:236-249.

82 Blankenberg S, Godefroy T, Poirier O, Rupprecht HJ, Barbaux S, Bickel C, Nicaud V, Schnabel R, Kee F, Morrison C, Evans A, Lackner KJ, Cambien F, Munzel T, Tiret L: Haplotypes of the caspase-1 gene, plasma caspase-1 levels, and cardiovascular risk. Circ Res 2006;99:102-108.
83 McAlindon ME, Hawkey CJ, Mahida YR: Expression of interleukin 1 beta and interleukin 1 beta converting enzyme by intestinal macrophages in health and inflammatory bowel disease. Gut 1998;42:214-219.

84 Johansen C, Moeller K, Kragballe K, Iversen L: The activity of caspase-1 is increased in lesional psoriatic epidermis. J Invest Dermatol 2007; 127:2857-2864.

85 Ona VO, Li M, Vonsattel JP, Andrews LJ, Khan SQ, Chung WM, Frey AS, Menon AS, Li XJ, Stieg PE, Yuan J, Penney JB, Young AB, Cha JH, Friedlander RM: Inhibition of caspase-1 slows disease progression in a mouse model of Huntington's disease. Nature 1999; 399:263-267.

86 Aganna E, Martinon F, Hawkins PN, Ross JB, Swan DC, Booth DR, Lachmann HJ, Bybee A, Gaudet R, Woo P, Feighery C, Cotter FE, Thome M, Hitman GA, Tschopp J, McDermott MF: Association of mutations in the NALP3/CIAS1/PYPAF1 gene with a broad phenotype including recurrent fever, cold sensitivity, sensorineural deafness, and AA amyloidosis. Arthritis Rheum 2002;46: 2445-2452.

87 Brenner M, Ruzicka T, Plewig G, Thomas P, Herzer P: Targeted treatment of pyoderma gangrenosum in PAPA (pyogenic arthritis, pyoderma gangrenosum and acne) syndrome with the recombinant human interleukin-1 receptor antagonist anakinra. $\mathrm{Br} \mathrm{J}$ Dermatol 2009;161:1199-1201.

88 Watanabe H, Gaide O, Petrilli V, Martinon F, Contassot E, Roques S, Kummer JA, Tschopp J, French LE: Activation of the IL$1 \beta$-processing inflammasome is involved in contact hypersensitivity. J Invest Dermatol 2007;127:1956-1963.

89 Sutterwala FS, Ogura Y, Szczepanik M, LaraTejero M, Lichtenberger GS, Grant EP, Bertin J, Coyle AJ, Galan JE, Askenase PW, Flavell RA: Critical role for NALP3/CIAS1/Cryopyrin in innate and adaptive immunity through its regulation of caspase-1. Immunity 2006;24:317-327.

90 Jin Y, Mailloux CM, Gowan K, Riccardi SL, LaBerge G, Bennett DC, Fain PR, Spritz RA: NALP1 in vitiligo-associated multiple autoimmune disease. N Engl J Med 2007;356: 1216-1225.

91 Murdoch S, Djuric U, Mazhar B, Seoud M, Khan R, Kuick R, Bagga R, Kircheisen R, Ao A, Ratti B, Hanash S, Rouleau GA, Slim R: Mutations in NALP7 cause recurrent hydatidiform moles and reproductive wastage in humans. Nat Genet 2006;38:300-302.

92 Larsen CM, Faulenbach M, Vaag A, Volund A, Ehses JA, Seifert B, Mandrup-Poulsen T, Donath MY: Interleukin-1-receptor antagonist in type 2 diabetes mellitus. N Engl J Med 2007;356:1517-1526.
93 Omi T, Kumada M, Kamesaki T, Okuda H, Munkhtulga L, Yanagisawa Y, Utsumi N, Gotoh T, Hata A, Soma M, Umemura S, Ogihara T, Takahashi N, Tabara Y, Shimada K, Mano H, Kajii E, Miki T, Iwamoto S: An intronic variable number of tandem repeat polymorphisms of the cold-induced autoinflammatory syndrome 1 (CIAS1) gene modifies gene expression and is associated with essential hypertension. Eur J Hum Genet 2006;14:1295-1305.

94 Jeru I, Duquesnoy P, Fernandes-Alnemri T, Cochet E, Yu JW, Lackmy-Port-Lis M, Grimprel E, Landman-Parker J, Hentgen V, Marlin S, McElreavey K, Sarkisian T, Grateau G, Alnemri ES, Amselem S: Mutations in NALP12 cause hereditary periodic fever syndromes. Proc Natl Acad Sci USA 2008; 105:1614-1619.

95 de Rivero Vaccari JP, Lotocki G, Alonso OF, Bramlett HM, Dietrich WD, Keane RW: Therapeutic neutralization of the NLRP1 inflammasome reduces the innate immune response and improves histopathology after traumatic brain injury. J Cereb Blood Flow Metab 2009;29:1251-1261.

96 Bulosan M, Pauley KM, Yo K, Chan EK, Katz J, Peck AB, Cha S: Inflammatory caspases are critical for enhanced cell death in the target tissue of Sjögren's syndrome before disease onset. Immunol Cell Biol 2009;87:8190.

-97 Saleh M, Vaillancourt JP, Graham RK, Huyck M, Srinivasula SM, Alnemri ES, Steinberg $\mathrm{MH}$, Nolan V, Baldwin CT, Hotchkiss RS, Buchman TG, Zehnbauer BA, Hayden MR, Farrer LA, Roy S, Nicholson DW: Differential modulation of endotoxin responsiveness by human caspase-12 polymorphisms. Nature 2004;429:75-79.

98 Denecker G, Hoste E, Gilbert B, Hochepied T, Ovaere P, Lippens S, Van den Broecke C, Van Damme P, D'Herde K, Hachem JP, Borgonie G, Presland RB, Schoonjans L, Libert C, Vandekerckhove J, Gevaert K, Vandenabeele P, Declercq W: Caspase-14 protects against epidermal UVB photodamage and water loss. Nat Cell Biol 2007;9:666-674.

99 Villani AC, Lemire M, Fortin G, Louis E, Silverberg MS, Collette C, Baba N, Libioulle C, Belaiche J, Bitton A, Gaudet D, Cohen A, Langelier D, Fortin PR, Wither JE, Sarfati M, Rutgeerts P, Rioux JD, Vermeire S, Hudson TJ, Franchimont D: Common variants in the NLRP3 region contribute to Crohn's disease susceptibility. Nat Genet 2009;41:71-76. 